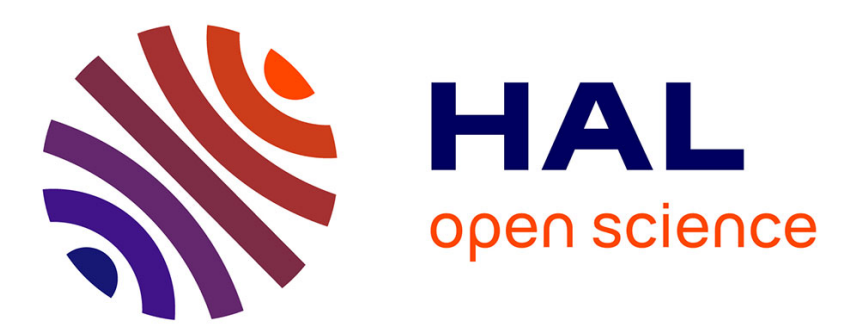

\title{
REPEATING "YES" IN A FIRST REQUEST AND COMPLIANCE WITH A LATER REQUEST: THE FOUR WALLS TECHNIQUE
}

Didier Courbet, Nicolas Guéguen, Severine Halimi, Robert-Vincent Joule, Marie Marchand

\section{To cite this version:}

Didier Courbet, Nicolas Guéguen, Severine Halimi, Robert-Vincent Joule, Marie Marchand. REPEATING "YES" IN A FIRST REQUEST AND COMPLIANCE WITH A LATER REQUEST: THE FOUR WALLS TECHNIQUE. Social behavior and personality, 2013, 41 (2), pp.199-202. sic_00870107

\section{HAL Id: sic_00870107 \\ https://archivesic.ccsd.cnrs.fr/sic_00870107}

Submitted on 5 Oct 2013

HAL is a multi-disciplinary open access archive for the deposit and dissemination of scientific research documents, whether they are published or not. The documents may come from teaching and research institutions in France or abroad, or from public or private research centers.
L'archive ouverte pluridisciplinaire HAL, est destinée au dépôt et à la diffusion de documents scientifiques de niveau recherche, publiés ou non, émanant des établissements d'enseignement et de recherche français ou étrangers, des laboratoires publics ou privés. 


\title{
REPEATING "YES" IN A FIRST REQUEST AND COMPLIANCE WITH A LATER REQUEST: THE FOUR WALLS TECHNIQUE
}

\author{
Nicolas GuÉGUEN \\ University of South Brittany \\ Robert-Vincent Joule, Didier Courbet, SÉverine Halimi-Falkowicz, \\ AND MARIE MARCHAND \\ University of Provence
}

\begin{abstract}
The commitment/consistency principle for compliance implies that people act in ways consistent with their previous behavior. Cialdini and Sagarin (2005) have stated that, according to this principle, asking individuals questions to which they would be expected to say "yes" could be associated with achieving greater compliance with a subsequent request. However, this procedure, referred to as the four walls technique, has never been tested experimentally. In this study, we conducted an experiment in which participants were first asked to answer several questions that required "yes" or "no" responses. Then, the participants were asked to comply with an additional request. It was found that saying "yes" several times beforehand is associated with greater compliance with a subsequent request than is saying "no" beforehand or when no first request was made.
\end{abstract}

Keywords: compliance, four walls technique, behavioral consistency, foot-in-the-door technique.

In 1966, Freedman and Fraser convinced $43 \%$ of a group of housewives to allow a team of five or six investigators to come to their homes for two hours to do an inventory of all the products they used for cleaning and cooking. Three days before this visit, the women were asked to fill out a short questionnaire containing eight questions concerning their household product consumption. Without this

\footnotetext{
Nicolas Guéguen, Department of Social Sciences, University of South Brittany; Robert-Vincent Joule, Didier Courbet, Séverine Halimi-Falkowicz, and Marie Marchand, Department of Social Psychology, University of Provence.

Correspondence concerning this article should be addressed to: Nicolas Guéguen, Université de Bretagne-Sud, UFR LSHS, 4 rue Jean Zay, BP 92116, 56321 Lorient Cedex, France. Email: nicolas. gueguen@univ-ubs.fr
} 
preliminary request, only $22 \%$ of the women agreed to the investigators' visit. The act of preparing the individual with a small request before making the sought after request has been called the foot-in-the-door (FITD; Freedman \& Fraser, 1966) technique. Various meta-analyses of numerous studies on this technique have shown its effects on compliance (Beaman, Cole, Preston, Klentz, \& Steblay, 1983; Burger, 1999; Dillard, Hunter, \& Burgoon, 1984; Fern, Monroe, \& Avila, 1986; Pascual \& Guéguen, 2005). One aspect that has not previously been tested using the FITD technique is the verbal behavior of individuals during the first request, and particularly the fact that when they respond to this request, they are required to answer "yes" or "no". When individuals are asked to comply with a second request, they may be influenced by their previous responses.

The assumption that the verbal behavior of a participant when fulfilling a first request may influence the rate of compliance with a second request was made by Cialdini and Sagarin (2005). In their study, they illustrated the frequent practice of door-to-door salesmen, who use such a method to gain permission to enter a customer's house. This approach, called the four walls (FW) technique, consists of asking the customer several initial questions to obtain "yes" to each request (e.g., "Do you feel that a good education is important for your children?"). After obtaining several "yes" answers, the seller then explains what product or service he/she has to offer and asks the customer for permission to enter. To our knowledge, and according to Cialdini and Sagarin, this technique has never been investigated experimentally. Therefore, this was our objective.

\section{Method}

\section{Participants}

The participants comprised 90 men (aged between 30 and 50 years), unaccompanied and chosen at random from the streets of a medium-sized town located on the south coast of Brittany, France. The participants were then selected to integrate 1 of 3 experimental conditions (two experimental conditions and one control condition), according to random distribution.

\section{Procedure}

A 20-year-old woman acted as a confederate. When the confederate saw a potential participant, she approached him. In both experimental conditions, the confederate asked the participant if he would agree to respond to a short 8-question survey on odd jobs in the home by responding either "yes" or "no". If the man agreed, the survey questions were read out. In the "yes" response condition, the questions were designed to obtain a "yes" answer to each question (e.g., "Have you ever assembled a storage unit?"), while in the "no" response condition, the questions were designed to obtain a "no" answer to each question 
(e.g., "Have you ever installed a solar water-heater?"). In both experimental conditions, the questions were tested for their ability to obtain "yes" or "no" responses to each question with a very large majority. (The pretest was conducted with a sample of 22 undergraduate students comprising 12 men and 10 women with a mean age of 20 years, $S D=1.2$ ) After completion of the survey, the confederate thanked the participant and then said, "I have something else to ask you. We are conducting a very important survey on people's food habits. Would you be willing to participate in this survey? The procedure is to take this stamped, addressed envelope (the confederate showed a 12.2" $\times 8.8$ " stamped, addressed envelope) in which you will find 45 questions on people's food habits. You may fill out this survey at home and then send back the questionnaire in the envelope provided. Would you care to do this?" In the control condition, the participant was approached in the same manner, but this latter request only was made. In all three conditions, the confederate waited for the participant's response before proceeding with a full debriefing.

\section{Results}

In the "yes" response condition, we found that $83.3 \%$ (25/30) of participants agreed with the request, whereas only $60 \%$ (18/30) in "no" response condition and 30\% (9/30) in the control condition agreed. Taking the number of participants agreeing to a request, independent chi square and phi coefficient test analyses of the 3 (experimental condition) $\times 2$ (compliance) design revealed a significant effect $\left(\chi^{2}(2, N=90)=17.58, p<.001, \varphi=.40\right)$. Additional analyses showed that the "yes" response condition was statistically different from both the "no" response condition $\left(\chi^{2}(1, N=60)=4.02, p<.05, \varphi=.25\right)$ and the control condition $\left(\chi^{2}(1, N=60)=17.37, p<.001, r=.47\right)$. Comparison between the "no" response condition and the control condition was significant $\left(\chi^{2}(1, N=60)\right.$ $=5.45, p<.02, \varphi=.29)$.

\section{Discussion}

In this experiment, we found that asking participants several questions to which they responded "yes" was associated with greater compliance with a later request. We, thus, note that this FW technique is more efficient in terms of gaining compliance than if they were asked questions to which they responded "no". However, in the case of people being induced to respond "no" several times, it was found that the participants' rate of compliance was statistically greater than when no initial request was used. Thus, it seems that when people respond "no" to the initial question of a first request, the classic FITD effect occurs, while for the FW condition, an independent effect is added to the FITD. 
This enhances the efficiency of the well-known FW technique, which had never before been investigated experimentally. Our results confirmed the assumption made by Cialdini and Sagarin (2005) that the FW technique is efficient for gaining compliance, and could thus be considered as a new compliance-gaining procedure (Pratkanis, 2007).

\section{References}

Beaman, A. L., Cole, C. M., Preston, M., Klentz, B., \& Steblay, N. M. (1983). Fifteen years of footin-the-door research: A meta-analysis. Personality and Social Psychology Bulletin, 9, 181-196. http://doi.org/dhjn4r

Burger, J. M. (1999). The foot-in-the-door compliance procedure: A multiple-process analysis and review. Personality and Social Psychology Review, 3, 303-325. http://doi.org/csc

Cialdini, R. B., \& Sagarin, B. J. (2005). Interpersonal influence. In T. Brock \& M. Green (Eds.), Persuasion: Psychological insights and perspectives (pp. 143-169). Newbury Park, CA: Sage.

Dillard, J., Hunter, J., \& Burgoon, M. (1984). Sequential-request persuasive strategies: Meta-analysis of foot-in-the-door and door-in-the-face. Human Communication Research, 10, 461-488. http:// doi.org/cr8ggb

Fern, E. F., Monroe, K. B., \& Avila, R. A. (1986). Effectiveness of multiple request strategies: A synthesis of research results. Journal of Marketing Research, 23, 144-152.

Freedman, J., \& Fraser, S. (1966). Compliance without pressure: The foot-in-the-door technique. Journal of Personality and Social Psychology, 4, 195-202. http://doi.org/csh

Pascual, A., \& Guéguen, N. (2005). Foot-in-the-door and door-in-the-face: A comparative meta-analytic study. Psychological Reports, 96, 122-128. http://doi.org/fdf2sw

Pratkanis, A. R. (Ed.). (2007). The science of social influence: Advances and future progress. New York: Psychology Press. 